\section{Improving Critical Thinking Skills and Learning Independence Using Problem Based Learning Based On Science Literation}

\author{
Rubiyanti ${ }^{*}$, Badarudin ${ }^{2}$, Karma Iswasta Eka ${ }^{3}$ \\ Elementary School Teacher Education \\ Universitas Muhammadiyah Purwokerto ${ }^{123}$ \\ Email: rubiadhi15@gmail.com*
}

http://ojs.unm.ac.id/index.php/Insani/index

Abstract. The purpose of this study is to improve critical thinking skills and student learning independence using Problem Based Learning (PBL) models based on scientific literacy. The research used is PTK with 2 cycles and each cycle is carried out in 2 meetings, each meeting consisting of planning, action, observation, and reflection. The tools used to collect data are written test questions, observation sheets of teacher and student activities, observation sheets for learning independence attitude, questionnaire on learning independence attitude scale, and documentation. Subjects in this study were 28 students. The results showed that the first cycle students gained critical thinking skills with an average of 2.6 with enough categories, increased in cycle II to 3.6 with good categories. Learning independence in cycle I gained an average of 3.85 in the good category and increased in the second cycle to 3.9 in the good category. This proves that with PBL based on scientific literacy can improve critical thinking skills and independence of learning.

Keywords: Critical Thinking, Independence of Learning, Problem Based Learning

\section{INDONESIAN JOURNAL OF EDUCATIONAL STUDIES (IJES)}

\section{E-ISSN: 2621-6744 \\ P-ISSN: 2621-6736}

Submitted: April, $3^{\text {rd }} 2020$

Accepted: May, $10^{\text {th }} 2020$

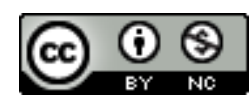

This work is licensed under a Creative Commons Attribution-NonCommercial 4.0 International License 


\section{INTRODUCTION}

21st century life requires humans to improve their quality of life. Improving the quality of human life aims to enable people to face 21st century competition that is not easy. One of the ways to improve the quality of life is by increasing the skills and attitudes that can be obtained through education. Education is expected to prepare students to develop skills and attitudes appropriate to the 21st century, so that students become successful individuals in life. Skills and attitudes relevant to the 21st century are relevant to the four pillars of education put forward by UNESCO (Sudarisman, 2015) that education includes learning to know, learning to do, learning to be and learning to live together. The four pillars each contain 21st century skills and attitudes that need to be developed through activities in education.

21st century educational activities are inseparable from the existence of literacy. The literacy is intended to develop a student's literacy culture. Literacy is usually applied before learning begins. Literacy in the 21st century is one of them is scientific literacy. The existence of scientific literacy is expected to be able to apply the concepts of science with phenomena that often occur in everyday life (Fanata, 2017: 4). Science literacy that is applied before learning begins is related to thematic learning. Thematic learning focuses on students and teachers as facilitators and motivators, so students can be actively involved in learning and can develop students' thinking skills. The skills that are enhanced in learning are critical thinking skills. The critical thinking skills are in line with the opinions of Hidayat, Mawardi, and Astuti (2019) which states that critical thinking becomes important for students because critical thinking is needed in learning activities as well as in life in society.

Learning is not only in terms of knowledge and skills, but also attitude. The importance of learning independence is in line with the opinion of Rafika, Israwati, and Bachtiar (2017) which states that with learning independence students are able to make choices that are considered correct, responsible, and the consequences resulting from these choices. Student learning independence needs to be instilled since elementary school, because student learning independence influences critical thinking skills.

Based on the results of interviews and observations in some schools, there are problems in learning that are quite serious, one of them is about the problem of critical thinking and learning independence. The learning carried out does not use a varied learning model, so that learning becomes passive. Students only listen, and record what is conveyed by the teacher and answer questions raised by the teacher. The learning model used so far has not activated students because learning is still dominated by teachers. The learning process that has been going on also still uses students' ability to memorize so that students have low-level abilities. Integrated thematic learning content of science requires active student involvement to develop their ability to analyze and so that critical thinking skills can be developed (Harahap, 2017). The daily activities of students in learning only write the essence of the material to the blackboard, and work on the questions that are on the worksheet sheets individually. 
Implementation of learning that has not used a variety of models and is still teacher-centered, resulting in students to find their own knowledge is very low. The learning that has been carried out has not yet involved the material with real life so students have not been able to argue to solve problems related to the real world, explain facts based on experiments, and draw conclusions based on evidence related to the content of science in progress.

The need for the development of learning independence of students in science content is also supported by the opinions of experts, as stated by Wulandari. Wulandari (2015) argues that teachers in learning are no longer the main and only source of learning, but students must actively find out through many other learning resources, students do things on their own conscious basis, and are not easily influenced by all decisions made was taken. Learning that took place in the science content of the independence of learning has not been well developed among students. Students still consider the teacher is the only source of knowledge, so that it is difficult for students to develop their abilities, including in critical thinking and students also have a dependency with others, especially teachers. Yet according to Susilowati (2018) argues that students have their own initiative without the help of others in determining learning resources and taking responsibility for themselves. Students in learning also tend to be passive, only receive information, rarely ask questions about material that is not understood, and students often experience doubts both in solving problems and in completing assignments so students still see the answers of their friends because they do not believe in their own abilities. Students when getting assignments are still joking, less serious, and have not been able to complete the task with responsibility.

Based on the results of discussions conducted together with class teachers, researchers collaborate to improve critical thinking skills and learning independence using the Problem Based Learning (PBL) model. Walfajri, and Harjono (2019) argue that the application of PBL models can improve critical thinking skills and learning outcomes. Badarudin (2018) PBL as one of the learning models characterized by the use of real life problems as something students must learn. Susilowati (2018) believes that the use of the PBL model can foster student learning independence. Pebriana and Disman (2017) argue that students with learning using the PBL model can increase critical thinking skills compared to students who learn to use conventional models. Handayani (2018) integrative thematic learning module with PBL models developed effectively to improve student learning outcomes and independent learning. The existence of these improvements and differences, the researchers are interested in using PBL in hopes of being able to improve critical thinking skills and student learning independence. The innovation in this research is the existence of scientific literacy as an introduction to present a problem related to student life in learning.

\section{RESEARCH METHOD}

This study uses classroom action research conducted in class $\mathrm{V}$ of MIM Kramat in the academic year 2019/2020. The subjects of this study were all fifth grade students at the Kramat MIM 2019/2020 school year. The number of students in the fifth grade of MIM Kramat is 28 students, with the number of boys being 19 
students and 9 girls Class action research according to Arikunto, Suhardjono, and Supardi (2015) is a study that describes the occurrence of cause and effect from the treatment, as well as describing what happens when the treatment is given, and describes the whole process from the initial treatment to the impact of the treatment. The treatment of these actions in the form of solutions in improving learning in the classroom. Class teachers are people who will implement solutions to improvement in learning. This research model uses a class action research model from Kemmis and Mc. Taggart. This research model according to Kemmis and Mc. Taggart (Hidayat and Badrujaman (2009)) consists of four steps, namely planning, action, observation, and reflection.

Data collection techniques used in this classroom action research, namely, in the form of tests and non-tests. The test technique that will be used is the description test to find out the students' critical thinking skills. The description test is done at the end of the lesson. The description test consists of questions that are adjusted with indicators of critical thinking skills, namely providing simple explanations, building basic skills, concluding, giving further explanations, and arranging strategies and tactics (Susanto, 2016: 125-126). The questions from this description test also adjust to the material in the theme. The number of questions in the description test are 5 items. The test is carried out at the end of learning. Nontest technique is carried out to find out the actual situation in the classroom during the learning process in the form of observation, a questionnaire on the scale of learning independence that contains statements that are in accordance with indicators of student learning independence, these indicators include being able to complete assignments and take responsibility, able to overcome problems, and believe in their own abilities (Maga, 2016), with the number of statements 7 negative statements, 7 positive statements, and documentation.

Analysis of the data used to measure critical thinking skills and learning independence, namely:

Score each indicator of critical thinking skills

Indicator Value $=\frac{\text { Number of subindicator weights } x \text { subindicator value }}{\text { Number of Weights }}$

(Arikunto and Jabar, 2010)

The criteria for critical thinking skills in students can be seen in table 1 as follows:

Table 1. Criteria for Students' Critical Thinking Skills

\begin{tabular}{ll}
\hline $\begin{array}{c}\text { Average } \\
\text { Answer Score }\end{array}$ & \multicolumn{1}{c}{ Criteria } \\
\hline$>4,2-5,0$ & Students' critical thinking skills are very good \\
\hline$>3,4-4,2$ & Students' critical thinking skills are good \\
\hline$>2,6-3,4$ & Students' critical thinking skills are sufficient \\
\hline$>1,8-2,6$ & Students' critical thinking skills are lacking \\
\hline $1,0-1,8$ & Students' critical thinking skills are very lacking \\
\hline
\end{tabular}

(Widoyoko, 2018: 112) 
Score each indicator of student learning independence Indicator Value $=\frac{\text { Number of subindicator weights } x \text { subindicator value }}{\text { Jumlah BoboNumber of Weightst }}$

(Arikunto and Jabar, 2010: 38)

Criteria for independence of student learning can be seen in table 2 as follows:

Table 2. Criteria for Student Learning Independence

\begin{tabular}{ll}
\hline $\begin{array}{c}\text { Average } \\
\text { Answer Score }\end{array}$ & \multicolumn{1}{c}{ Criteria } \\
\hline$>4,2-5,0$ & Student learning independence is very good \\
\hline$>3,4-4,2$ & Student learning independence is good \\
\hline$>2,6-3,4$ & Student learning independence is sufficient \\
\hline$>1,8-2,6$ & Student learning independence is lacking \\
\hline $1,0-1,8$ & Student learning independence is very lacking \\
\hline
\end{tabular}

(Widoyoko, 2018: 112)

\section{RESULTS AND DISCUSSION}

The results showed that PBL models based on scientific literacy can improve critical thinking skills and student learning independence. This is evidenced by the increase in the average test of critical thinking skills, observations and questionnaires on the scale of students' learning independence attitude. Students at the end of the lesson are given a critical thinking skills test consisting of 5 problem descriptions and each question is adjusted to the indicator of critical thinking skills. Increased critical thinking skills can be seen in the table 3 below:

Table 3. Increased Critical Thinking Skills

\begin{tabular}{clcc}
\hline No. & Indicators of Critical Thinking Skills & Cycle I & Cycle II \\
\hline 1 & Provide a Simple Explanation & 2.45 & 4.4 \\
2 & Building Basic Skills & 4 & 4.05 \\
3 & Conclude & 3.6 & 3.4 \\
4 & Provide Further Explanation & 2.35 & 2.9 \\
5 & Set Strategy and Tactics & 1.1 & 3.1 \\
& Amount & 27 & 35.7 \\
& Average & 2.6 & 3.6 \\
& Criteria & Sufficient & Good \\
\hline
\end{tabular}

Based on table 3 it can be seen that the critical thinking skills of students from cycle I and cycle II have increased. The increase that occurred from the first cycle and second cycle is 1.0. This is because the PBL model that has been implemented can improve students 'critical thinking skills in making analyzes, 
solving problems, concluding solving problems based on facts, so that students' critical thinking skills can improve. The results of students' learning independence attitudes were obtained by the questionnaire on learning independence attitude scale. Questionnaire scale on the attitude of learning independence is filled in by students at the end of learning after completing the critical thinking skills test. The results of student learning independence are as follows:

Table 4. Questionnaire Scale for Learning Independence Attitudes

\begin{tabular}{|c|c|c|c|c|}
\hline No & Indicator & Statement & $\begin{array}{l}\text { Average } \\
\text { Cycle I }\end{array}$ & $\begin{array}{c}\text { Average } \\
\text { Cycle II }\end{array}$ \\
\hline \multirow[t]{4}{*}{1} & $\begin{array}{l}\text { Able } r o \\
\text { complete tasks }\end{array}$ & $\begin{array}{l}\text { I participated in carrying out } \\
\text { group assignments }\end{array}$ & 81 & $105 \cdot 5$ \\
\hline & $\begin{array}{l}\text { and } \\
\text { responsibilities }\end{array}$ & $\begin{array}{l}\text { I am not serious in doing my } \\
\text { work }\end{array}$ & 75.5 & 96 \\
\hline & & $\begin{array}{l}\text { I was not serious in following } \\
\text { the lesson }\end{array}$ & 72.5 & 90.5 \\
\hline & & $\begin{array}{l}\text { I am on time in completing } \\
\text { assignments }\end{array}$ & 76 & 96.5 \\
\hline \multirow[t]{6}{*}{2} & $\begin{array}{l}\text { Able } \\
\text { overcome } \\
\text { problems }\end{array}$ & $\begin{array}{l}\text { When I didn't understand } \\
\text { how to complete the task, I } \\
\text { searched for answers through } \\
\text { books or the internet }\end{array}$ & 67.5 & 87.5 \\
\hline & & $\begin{array}{l}\text { When I did not understand } \\
\text { what the teacher was } \\
\text { teaching, asking questions to } \\
\text { the teacher }\end{array}$ & 76.5 & 94.5 \\
\hline & & $\begin{array}{l}\text { I do not answer the teacher's } \\
\text { question, if the teacher asks }\end{array}$ & 73.5 & 95 \\
\hline & & $\begin{array}{l}\text { When discussing, I do not } \\
\text { propose opinions }\end{array}$ & 68.5 & 81 \\
\hline & & $\begin{array}{l}\text { I respond to friends' answers } \\
\text { when discussing }\end{array}$ & 69 & 89 \\
\hline & & $\begin{array}{l}\text { When there's something new, } \\
\text { I'm not curious about it }\end{array}$ & 55.5 & 67 \\
\hline \multirow[t]{5}{*}{3} & Believe in your & I study not by myself & 65.5 & 74.5 \\
\hline & own abilities & I learn my way & 67.5 & 91.5 \\
\hline & & $\begin{array}{l}\text { I work on problems with the } \\
\text { help of others }\end{array}$ & 63 & 84.5 \\
\hline & & $\begin{array}{l}\text { overcame my own } \\
\text { difficulties in learning }\end{array}$ & $77 \cdot 5$ & $94 \cdot 5$ \\
\hline & & $\begin{array}{l}\text { Average } \\
\text { Criteria }\end{array}$ & $\begin{array}{l}3.85 \\
\text { Good }\end{array}$ & $\begin{array}{l}3.9 \\
\text { Good }\end{array}$ \\
\hline
\end{tabular}

Based on table 4, it can be seen an increase in student learning independence from the results of the questionnaire scale of students' learning 
independence attitude. Cycle I students get an average questionnaire scale of students 'attitude of learning independence of 3.85, while in the second cycle to obtain an average questionnaire scale of students' attitude of learning independence of 3.9. The increase that occurred from cycle I to cycle II was 0.05 . The increase occurred because in the first cycle students did not do anything during the experiment, this indicates less interest in new things, whereas in cycle II students have started to be interested in new things by showing they are active in conducting experiments. Cycle II students also began to dare to ask questions about things they did not understand, whereas in the previous cycle students did not ask questions about things they did not understand. Cycle I students did not dare to appear in front of the class, whereas in cycle II students had the courage to appear in front of the class.

\section{Increased Critical Thinking Skills}

At the end of learning using the PBL model, students take an evaluation test of critical thinking skills. The evaluation test is used to measure students' critical thinking skills. Students take an evaluation test of 5 items in the description. The description is related to the material contained in the theme 6 . The description of the problem is also adjusted to the indicators of critical thinking skills. Critical thinking skills indicators used for the measurement of critical thinking skills are critical thinking indicators according to Susanto (2016: 125-126). These indicators are 1) Providing simple explanations, 2) Building basic skills, 3) Summing up, 4) Providing further explanation, 5) Managing strategies and tactics.

Based on table 3, it can be seen the increase and decrease in each indicator. The increase occurred in indicator 1, namely providing a simple explanation, indicator 2, which is building basic skills, indicator 4, which is giving further explanation, and indicator 5 , which is building strategy or tactics. The decrease occurred in indicator 3, namely the conclusion because students in explaining the conclusion were not quite right. Students in the second cycle are able to analyze the cause of a problem, then conduct an experiment to solve a problem, and conclude the experiment based on the facts found in the experiment. This is consistent with the opinions of Indriyani, Mawardi, and Wardani. Indriyani, Mawardi, and Wardani (2019) argue that critical thinking is a student's skill in analyzing something by proving the truth not only from opinions or arguments but supported by truth or facts.

Important critical thinking skills possessed by students. Students who have critical thinking skills are expected to be able to solve problems related to real life or that students often encounter in daily life. This is consistent with the opinions of Asuan, Mawardi, and Wardani. Asuan, Mawardi, and Wardani (2019) argue that critical thinking is very important for students, because by thinking critically students can solve all the problems that exist in the real world. Learning to use PBL implemented in classrooms can be increased. This agrees with the opinion of Birgili (2015) who argues that there is something useful for the development of creativity and critical thinking skills, namely the problem-based learning environment in the classroom. PBL is a model that focuses on students. This is consistent with the opinion of Huda (2019: 271) that PBL focuses on student learning and not on teacher 
teaching. This is also in accordance with the 2013 curriculum whose learning focuses on students, teachers only as facilitators and motivators.

Based on table 3 it can be seen that the critical thinking skills of students from cycle I and cycle II have increased. The increase that occurred from the first cycle and second cycle is 1.0. This is because the PBL model that has been implemented can improve students 'skills in making analyzes, solving problems, concluding solving problems based on facts, so that students' critical thinking skills can improve.

\section{Independence of student learning}

Learning that is carried out using the PBL model involves students actively in learning. The teacher is only a facilitator and motivator. This is in agreement with Huda (2019: 271) who believes that PBL is focused on student learning and not on teacher teaching. Learning using the PBL model presents a problem at the beginning of learning which is presented in the form of scientific literacy, students look for the problem, and then students solve the problem, so students can understand the material with their own understanding. This is in accordance with the opinion of Wulandari (2015) who argues that with PBL students can compile their own knowledge about critical thinking, problem solving skills, gain knowledge, and essential concepts from the subject matter being studied.

Students in PBL learning that presents problems, then students solve these problems by conducting experiments, conducting discussions and looking for various sources of information so that the problem can be solved. This is in accordance with the opinion of Wulandari (2015) who argues that teachers in learning are no longer the main and only source of learning, but students must actively find out through many other learning resources, students do things on their own conscious basis, and not easily influenced by all decisions taken.

Based on table 4, it can be seen an increase in student learning independence from the results of the questionnaire scale of students' learning independence attitude. Cycle I students get an average questionnaire scale of students 'attitude of learning independence of 3.85, while in the second cycle to obtain an average questionnaire scale of students' attitude of learning independence of 3.9. The increase that occurred from cycle I to cycle II was 0.05 . Students have started to be interested in new things by showing they are already active in conducting experiments. Students also have begun to dare to ask questions about things they do not understand, whereas in the previous cycle students asked questions about things they did not understand. Cycle I students did not dare to appear in front of the class, whereas in cycle II students had the courage to appear in front of the class. Data taken to measure student learning independence from the scale of students' learning independence attitude scale has increased from cycle I to cycle II. This indicates that learning using PBL models based on science literacy can foster student learning independence in class $\mathrm{V} M I M$ Kramat on the theme of 6 . 


\section{CONCLUSION}

Based on research that has been carried out for 2 cycles to improve critical thinking skills and student learning independence using PBL models based on Literacy Science on the theme of 6 Panas dan Perpindahannya of the research results, namely:

1. The application of PBL models based on Science Literacy can improve students' critical thinking skills. The improvement was shown by the results of critical thinking skills tests, teacher activity sheets, and student activity sheets. Cycle I critical thinking skills of students have not yet reached the indicator of success, because there are several factors. Cycle II critical thinking skills have improved, and have achieved indicators of success in which as many as $70 \%$ of students have obtained critical thinking skills with good categories because in cycle II students are more active in learning and can understand the material. Teacher activities in learning greatly affect students in learning, it is seen when the teacher engages students in learning, then students are more active in learning and more enthusiastic so it makes it easy for students to understand the material. This is evident from the results of students' thinking skills tests in the first cycle to obtain enough categories. The increase occurred in cycle 2 with a good category.

2. The application of the PBL model based on Science Literacy can improve student learning independence. The increase was shown based on the results of observations of student learning independence, and questionnaire scale of students' learning independence attitude. The results of the questionnaire scale on the attitude of student learning independence in the first cycle obtained a good category. Increasing the scale of the attitude of students' learning independence attitude increased in the second cycle with the acquisition of good categories.

\section{REFERENCES}

Asuan., Mawardi., dan K. W. Wardani. (2019). Efektivitas Model Problem Based Learning dan Make A Match dalam Pembelajaran Tematik Kelas V SD Negeri Sidorejo Lor 04 yang Ditinjau dari Keterampilan Berpikir Kritis. Journal of Elementary Education, 3 (3), 275-283.

Arikunto, S., Suhardjono., dan Supardi. (2015). Penelitian Tindakan Kelas. Jakarta: Bumi Aksara.

Arikunto, S., dan C. S. A. Jabar. (2009). Evaluasi Program Pendidikan. Jakarta: Bumi Aksara.

Badarudin. (2018). Peningkatan Sikap Peduli Lingkungan dan Prestasi Belajar IPA menggunakan Model Problem Based Learning Berbasis Literasi pada Subtema Lingkungan Tempat Tinggalku di Kelas IV MI Muhammadiyah Kramat. Jurnal Pendidikan Dasar Indonesia, 3 (2), 50 - 56.

Birgili, B. (2015). Creative and Critical Thinking Skills in Problem Based Learning Environments. Journal of Gifted Education and Creativity, 2 (2), 71-80.

Fanata, M. R., dkk. (2017). Materi Pendukung Literasi Sains. Jakarta: Kementerian Pendidikan dan Kebudayaan. 
Handayani, M. (2018). Developing Thematic-Integrative Learning Module with Problem-Based Learning Model for Elementary School Students. Jurnal Prima Edukasia, 6 (2), 166-167.

Harahap, R. A. (2017). Peningkatan Kemampuan Berpikir Kritis, Kemandirian Belajar PKn Peserta Didik melalui Problem Based Learning. Jurnal Tematik, 6 (4), 59-72.

Hidayat, D. R., dan A. Badrujaman. (2009). Cara Mudah Melakukan Penelitian Tindakan Kelas. Jakarta: CV Trans Info Media

Hidayat, T., Mawardi., \& S. Astuti. (2019). Peningkatan Kemampuan Berpikir Kritis dan Hasil Belajar Siswa Kelas IV Melalui Model Pembelajaran Discovery Learning pada Tema Indahnya Keberagaman di Negeriku. Jurnal Pendidikan Unsika, 7 (1), 1-9.

Huda, M. (2019). Model-Model Pengajaran dan Pembelajaran. Yogyakarta: Pustaka Pelajar.

Indriyani, D., Mawardi., \& K. W. Wardani. (2019). Peningkatan Keterampilan Berpikir Kritis Melalui Model Inkuiri Berbantuan Media Konkret Pada Siswa Kelas 5 Sd Negeri Mangunsari 05 Tahun Pelajaran 2018/2019. Journal Research \& Learning in Elementary Education, 3 (1), 27-32.

Maga, Y. (2016). Peningkatan Kemandirian Belajar dan Hasil Belajar Matematika Melalui Strategi Metakognitif Berbasis Tutor Sebaya Bagi Siswa Kelas V SD YPK Persiapan Kampung Anny. Jurnal Surya, 14, 37-42

Pebriana, R., \& Disman. (2017), Effect of Problem Based Learning to Critical Thinking Skills Elementary School Students in Social Studies. Jurnal of Elementary Education, 1 (1), 109-118.

Rafika, Israwati, \& Bachtiar. (2017). Upaya Guru dalam Menumbuhkan Kemandirian Belajar Siswa di SD Negeri 22 Banda Aceh. Jurnal Ilmiah Pendidikan Guru Sekolah Dasar, 2 (1), 115-123.

Sudarisman, S. (2015). Memahami Hakikat dan Karakteristik Pembelajaran Biologi dalam Upaya Menjawab Tantangan Abad 21 serta Optimalisasi Implementasi Kurikulum 2013. Jurnal Florea, 2 (1), 29-35.

Susanto, A. (2016). Teori Belajar \& Pembelajaran di Sekolah Dasar. Jakarta: Prenadamedia Grup.

Susilowati, A. (2018). Pengaruh PBL terhadap Kemandirian Belajar Siswa SD. Journal of Primary Education, 2 (1), 72-77.

Walfajri, R. U., \& N. Harjono. (2019). Peningkatan Kemampuan Berpikir Kritis dan Hasil Belajar Tematik Muatan IPA melalui Model Problem Based Learning Kelas 5 SD. Jurnal Basicedu, 3 (1), 16-20.

Wulandari, E. T. (2015). Pengaruh Problem Based Learning terhadap Kemandirian Belajar IPA Siswa Kelas IV se-Gugus III Temon. Jurnal Pendidikan Guru Sekolah Dasar, 1137 (1009), 1-9.

Widoyoko, S. E. P. (2018). Teknik Penyusunan Instrumen Penelitian. Yogyakarta: Pustaka Pelajar 